\title{
Relationship between seasonal dynamics in zooplankton density and Ergasilus infection in two reservoirs
}

\author{
Eva Jelínková1, Ivo Krechler², Pavel Jurajda ${ }^{3}$, Ivana Papežíková1, Stanislav Navrátile, \\ Zdenka Marková1, Miroslava Palíková1 \\ ${ }^{1}$ University of Veterinary and Pharmaceutical Sciences Brno, Faculty of Veterinary Hygiene and Ecology, \\ Institute of Ecology and Diseases of Game, Fish and Bees, Czech Republic \\ ${ }^{2}$ Morava River Basin State Enterprise, Brno, Czech Republic \\ ${ }^{3}$ Academy of Sciences of the Czech Republic, Institute of Vertebrate Biology, \\ Brno, Czech Republic \\ Received January 14, 2017 \\ Accepted April 3, 2018
}

\begin{abstract}
Ergasilosis is a common parasitic disease of fish caused by species of the family Ergasilidae. During the fish growing season, parasitic abundance (including developmental stages) changes in relation to zooplankton development. In this study, we evaluated the seasonal dynamics of ergasilosis in relation to zooplankton development at two reservoirs (Hubenov, Koryčany) in the Morava River Basin (Czech Republic). Samples of fish and zooplankton were obtained at monthly intervals between April and October 2014. In total, 189 fish of 11 species were caught using electrofishing and seine nets. Overall, epidemiological characteristics were higher in the Hubenov reservoir, which also hosted higher numbers of pelagic Copepods. Hubenov also supported a higher number of predatory fish species, which presumably helped to reduce the number of zooplanktonophagic cyprinids. Our results suggest that each reservoir represents a unique ecosystem with its own pattern of ergasilosis seasonal development. Differences between reservoirs are closely related to zooplankton development, which is in turn affected by the fish stock in each reservoir. As the nauplius and copepod stages of arthropods form part of the zooplankton assemblage, they will be found at highest numbers in reservoirs where predatory fish suppress zooplanktonophagic fish species. We suggest to analyse zooplankton with the determination of the genus Ergasilus.
\end{abstract}

Parasite, ergasilosis, food web, biomanipulation, Hubenov, Koryčany

Representatives of the subclass Copepoda play an essential role as part of the food chain in aquatic ecosystems. These parasitic organisms form an integral part of the zooplankton assemblage during their free-living stage and represent a much sought-after food item of zooplanktonophagic fish (Dussart and Defaye 2001). Over the year, both quantitative and qualitative changes occur in zooplankton composition, with seasonal dynamics mainly affected by changes in abiotic and biotic factors, reservoir trophic status and fish predatory pressure (Wolfinbarger 1999; Pichlová and Brandl 2003; Sommer et al. 2012; Dvurechenskaya and Yermolaeva 2014). If predatory fish suppress zooplanktonophagic fish sufficiently, for example, the quantity of zooplankton increases, positively affecting the quality of raw drinking water (Tatrai et al. 2005; Bernes et al. 2015; Jurajda et al. 2016). On the other hand, such a reduction in cyprinids may increase the occurrence of parasites whose development is bound to that of zooplankton as the freeliving nauplius and copepod stages of parasites such as Ergasilus sieboldi Nordmann 1832, for example, form part of the zooplankton assemblage. In the life cycle of E. sieboldi are six free-swimming nauplii stages and five copepodite stages, from which free-swimming adult males and females develop. The development of the parasite usually lasts from 10 to 70 days depending on water temperature. Adult females then attach to the gills of many fish species, feeding on the gill epithelium and blood, eventually impairing the

\footnotetext{
Address for correspondence:

Mgr. Eva Jelínková

Department of Ecology and Diseases of Game, Fish and Bees,

Faculty of Veterinary Hygiene and Ecology

University of Veterinary and Pharmaceutical Sciences Brno

Palackého tř. 1946/1, 61242 Brno, Czech Republic
}

Phone: +420776643 122
E-mail: evickajelinkova@seznam.cz
http://actavet.vfu.cz/ 
respiratory function of the gills. When parasitic invasion is particularly high, or oxygen concentration particularly low, the affected fish may suffocate and die (Abdelhalim 1991; Hoole et al. 2001).

The seasonal development of ergasilosis usually starts in April and lasts until November. In Central Europe, the first spring generation reaches sexual maturity in mid-June, with the second generation appearing from mid-August to mid-September. Occasionally, a third generation may also develop at the end of the season (Lester and Hayward 2006). During the season parasite abundance changes, mainly in relation to zooplankton development. The second important factor affecting parasite abundance is water temperature, which the egg development in egg sacs is dependent on. In general, the higher the temperature the faster eggs develop, though a temperature of $3.6^{\circ} \mathrm{C}$ is thought to be sufficient for the onset of development (Piasecki et al. 2004).

Long-term ichthyological monitoring by the Morava River Basin State Enterprise in cooperation with the University of Veterinary and Pharmaceutical Sciences Brno indicates that ergasilosis is one of the most frequent fish diseases detected in reservoirs of the Morava River Basin (Czech Republic). Based on these results, it was decided to undertake a detailed survey of ergasilosis in relation to zooplankton development at two reservoirs differing in known intensity of ergasilosis and predatory fish stock. Here, we test the hypothesis that an increasing proportion of predatory fish in the fish assemblage will threaten the fish health status due to increased preponderance of E. sieboldi.

\section{Materials and Methods}

\section{Reservoir characteristics}

Two contrasting water-supply reservoirs under the management of the Morava River Basin State Enterprise, namely Hubenov and Koryčany, were used for this study. Experience has shown that intensity of infection and abundance of E. sieboldi tends to be higher at Hubenov compared to Koryčany. The two reservoirs also differ in typology and typography, i.e. altitude, area, depth, trophic status and fish stock composition. While predatory fish are stocked in both reservoirs to improve the quality of raw drinking water by suppressing zooplanktonophagic fish, Hubenov supports higher numbers of predatory fish (Ivo Krechler, personal communication).

The 55 ha Hubenov reservoir (Fig. 1) (49²3'41.7'N, 15²9'05.2'E; $524 \mathrm{~m}$ a.s.1.) is located in the Vysočina Region, $7.5 \mathrm{~km}$ from the town of Jihlava, and has served as a drinking water storage reservoir for the Jihlava region since 1972. It has a storage capacity of 2.4 million $\mathrm{m}^{3}$, a total volume of 3.4 million $\mathrm{m}^{3}$, and a maximum depth of $19.1 \mathrm{~m}$ (Kestřánek et al. 1984). In addition to providing drinking water, the reservoir secures a minimum river flow rate under the dam and helps prevent local flooding.

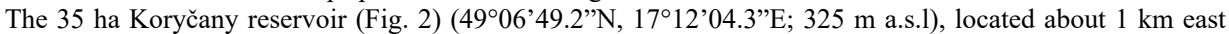
of Koryčany in the Zlín Region, first entered service in 1963. Koryčany fulfils a role in the landscape similar to Hubenov, with its main role being the supply of drinking water to the Kyjov Region. The maximum depth of the reservoir is $18.7 \mathrm{~m}$ (Kestř́nek et al. 1984) with a storage capacity of 2.1 million $\mathrm{m}^{3}$ and a total volume of 2.6 million $\mathrm{m}^{3}$.

Water temperature at both reservoirs is measured every day at 7:00 h by representatives of the Morava River Basin State Enterprise using a manually calibrated thermometer (H7 Hydro Controller, Fiedler AMS s.r.o., Czech Republic).

\section{Fish sampling and parasitological examination}

We undertook seven monthly fish surveys at each reservoir between April and October 2014. All fish were caught using electrofishing apparatus (EFKO FEG 13000, Honda $13 \mathrm{~kW}$, ca. 300 V, 60 A, BGTechnikcs, a.s., Czech Republic) and seine nets (30 m long, $4.5 \mathrm{~m}$ deep, with mesh sizes ranging from 70 to $135 \mathrm{~mm}$ ) (Figs 1 and 2), based on standard methodologies for fishing in still waters (Kubečka et al. 2010).

The fish were transferred alive to the laboratory, where they were humanely stunned and immediately killed before preparation for parasitological examination. Immediately prior to examination, each fish was determined as to the species, measured (total length [TL], $\mathrm{mm}$ ) and weighed (mg), and its nutritional status was assessed. Finally, scales were sampled for age determination and the gills examined for E. sieboldi parasites. The number of Ergasilus sp. was assessed macroscopically on all four pairs of gill arches and the species determined by microscopic examination (microscope Olympus, magnification $\times 40$, Olympus Czech Group, Praha) (Ergens and Lom 1970). The results are presented as infection intensity (number of individuals of a particular parasite species 

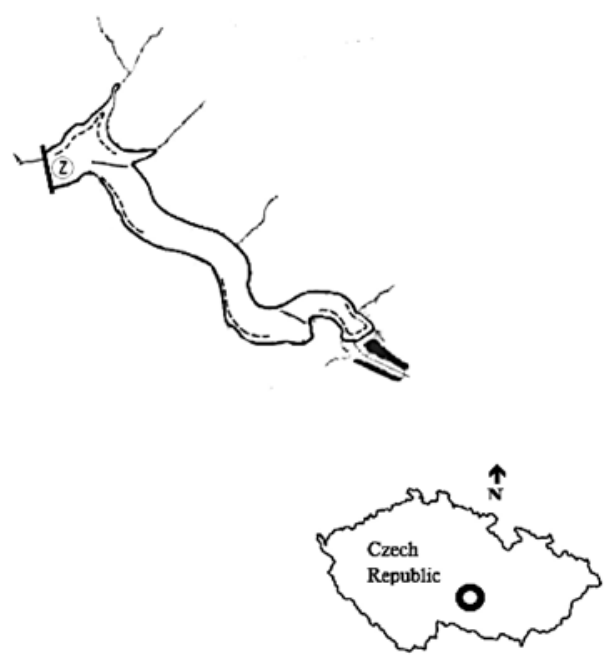

Fig. 1. Map of the Hubenov water-supply reservoir with sampling sites for pelagic zooplankton (Z) indicated, along with stretches where fish were sampled using seine nets (-) and electrofishing (---).

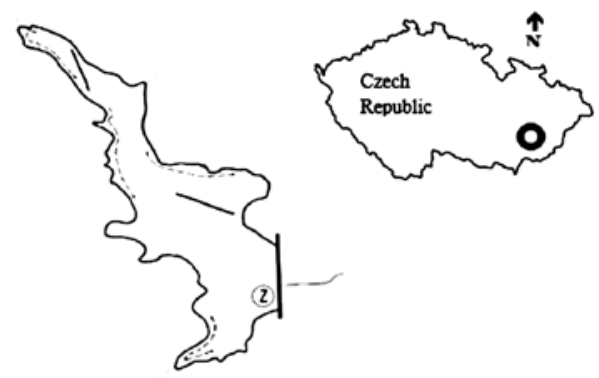

Fig. 2. Map of the Koryčany water-supply reservoir with sampling sites for pelagic zooplankton (Z) indicated, along with stretches where fish were sampled using seine nets (-) and electrofishing (---).

in a single infected host), abundance (number of individuals of a particular parasite in/on a single host regardless of whether or not the host is infected) and prevalence (percentage of the parasite-infected specimens in the fish species population) (Bush et al. 1997).

\section{Zooplankton sampling and processing}

Pelagic zooplankton samples were obtained from below the dam at each reservoir (Figs 1 and 2) at the same time as fish sampling between April and October 2014 using standard $80 \mu \mathrm{m}$ plankton nets with an Apstein extension. All samples were transferred to a clean container and preserved in $4 \%$ formaldehyde for further laboratory processing. In the laboratory, the sample was transferred into a Sedgwick-Rafter counting chamber and determination was undertaken using a microscope (microscope Olympus, magnification × 10, Olympus Czech Group, Praha) (Přikryl 2006). Only adult female or the highest copepod stages of $E$. siebold $i$ were determined as other forms are too difficult to determine reliably. It means that only the highest copepod and adult stagesof $E$. sieboldi were counted.

\section{Statistical analysis}

Analysis of variance (ANOVA) was used to evaluate changes in water temperatures over the year in and between the two reservoirs. After testing for normality using the Shapiro-Wilks test, Pearson's correlation coefficient was used to assess the relationship between mean intensity of infection by E. sieboldi and development of zooplankton in the reservoirs. All statistical analyses were undertaken using the UNISTAT statistical software package.

\section{Results}

During the seven fish surveys undertaken, we caught a total of 189 fish (Hubenov - 98, Koryčany- 91) of 11 species: common bream Abramis brama, northern pike Esox lucius, perch Perca fluviatilis, asp Leuciscus aspius, roach Rutilus rutilus, chub Squalius cephalus, rudd Scardinius erythrophthalmus, zander Sander lucioperca, bleak Alburnus alburnus, nase Chondrostoma nasus and an A. brama and $R$. rutilus hybrid (Table 1).

The highest overall values for $E$. sieboldi infection intensity and abundance were recorded at Hubenov in June and September, with a mean infection intensity of 94 individuals (ind) per fish during June and 145 ind per fish during September. Prevalence ranged between 
Table 1. Number, total length (TL, min-max) and age of fish caught in the Hubenov (Hub) and Koryčany (Kor) reservoirs during 2014.

\begin{tabular}{lcrrrrr}
\hline Species & \multicolumn{2}{c}{ Number } & \multicolumn{2}{c}{ TL $[\mathrm{mm}]$} & \multicolumn{2}{c}{ Age } \\
& Hub & Kor & Hub & Kor & Hub & Kor \\
\hline Abramis brama & 26 & 19 & $318-475$ & $228-375$ & $3-9+$ & $2-6+$ \\
Esox lucius & 15 & 18 & $434-530$ & $309-600$ & $2-6+$ & $1-6+$ \\
Perca fluviatilis & 16 & 14 & $205-346$ & $149-329$ & $2-6+$ & $2-5+$ \\
Leuciscus aspius & 17 & 12 & $413-568$ & $340-585$ & & \\
Rutilus rutilus & 14 & 8 & $140-310$ & $144-288$ & $2-8+$ & $2-4+$ \\
Squalius cephalus & 6 & 6 & $330-393$ & $204-410$ & $3-5+$ & $2-5+$ \\
Scardinius erythrophthalmus & 1 & 9 & 169 & $150-289$ & $3+$ & $3-5+$ \\
Sander lucioperca & 1 & 4 & 356 & $466-534$ & $3+$ & $3-5+$ \\
Alburnus alburnus & 0 & 1 & 0 & 164 & 0 & $2+$ \\
Chondrostoma nasus & 1 & 0 & 383 & 0 & $4+$ & 0 \\
Hybrid A. brama x R. rutilus & 1 & 0 & 310 & 0 & $6+$ & 0 \\
\hline
\end{tabular}

80 and 100\% between April and October (Fig. 3). Two peaks in mean infection intensity and abundance were also recorded at Koryčany, the first one in May (earlier than at Hubenov) and the second one around September and October. Mean infection intensity reached 65 ind per fish during May and 53 ind per fish during the second peak starting in September, with prevalence ranging between 33 and 100\% over the study (Fig. 4).

Copepoda numbers peaked in May, July and September in the Hubenov reservoir, and in May and September in Koryčany (Fig. 5).

No significant correlation was observed between seasonal E. sieboldi infection intensity and zooplankton development in the Hubenov reservoir $(\mathrm{r}=0.12, P>0.05)$, suggesting independent development (Fig. 6). In the Koryčany reservoir, however, the relationship between $E$. sieboldi infection intensity and zooplankton development was significant $(\mathrm{r}=0.72, P<0.05$; Fig. 7$)$.

Temperatures at the Hubenov reservoir tended to be lower than at Koryčany over the

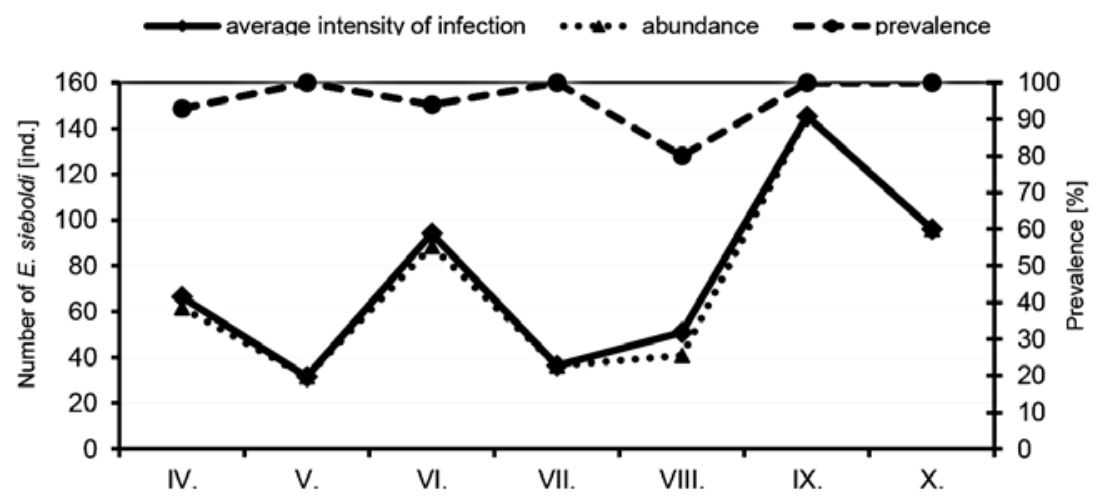

Fig. 3. Mean intensity (ind), abundance (ind) and prevalence (\%) of Ergasilus sieboldi in the Hubenov reservoir from April (IV) to October (X) 2014. 


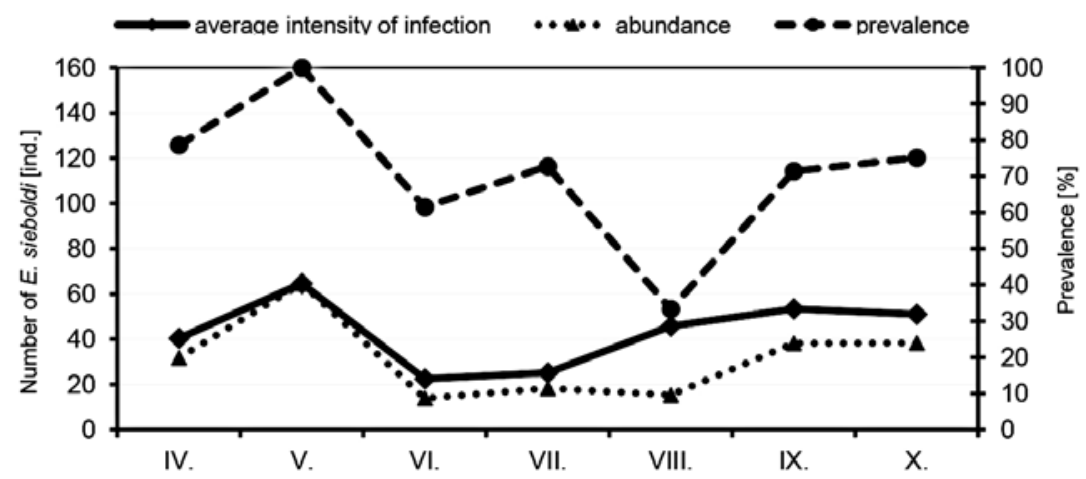

Fig. 4. Mean intensity (ind), abundance (ind), and prevalence (\%) of Ergasilus sieboldi in the Koryčany reservoir from April (IV) to October (X) 2014.

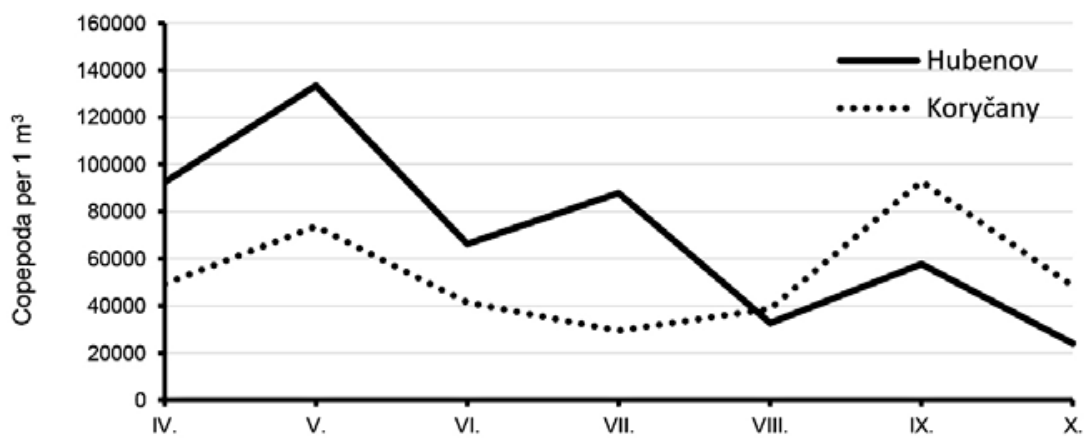

Fig. 5. Development of Copepoda in the Hubenov and Koryčany reservoirs from April (IV) to October (X) 2014 (Copepoda per $1 \mathrm{~m}^{3}$ ).

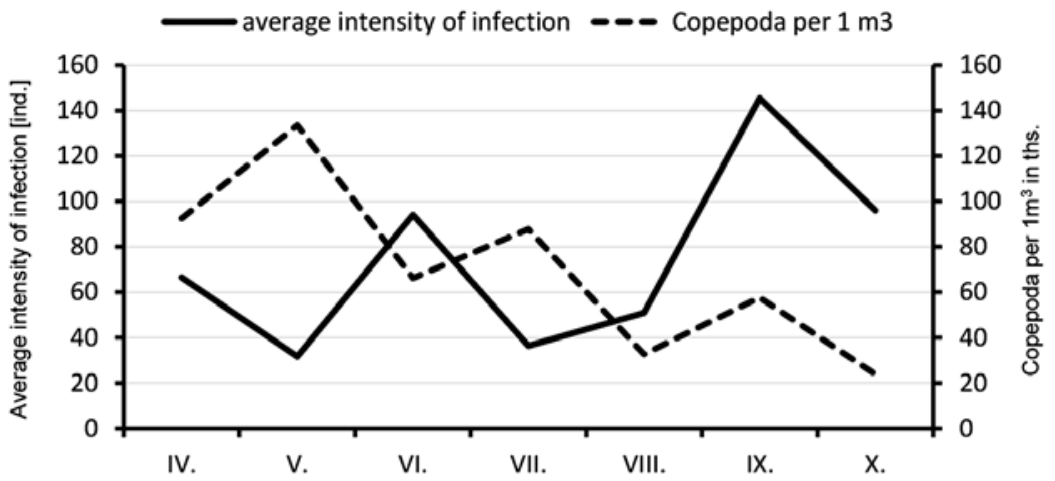

Fig. 6. Mean infection intensity of Ergasilus sieboldi (ind.) in relation to zooplankton development (Copepoda per $1 \mathrm{~m}^{3}$ in thousands) in the Hubenov reservoir from April (IV) to October (X) 2014. 


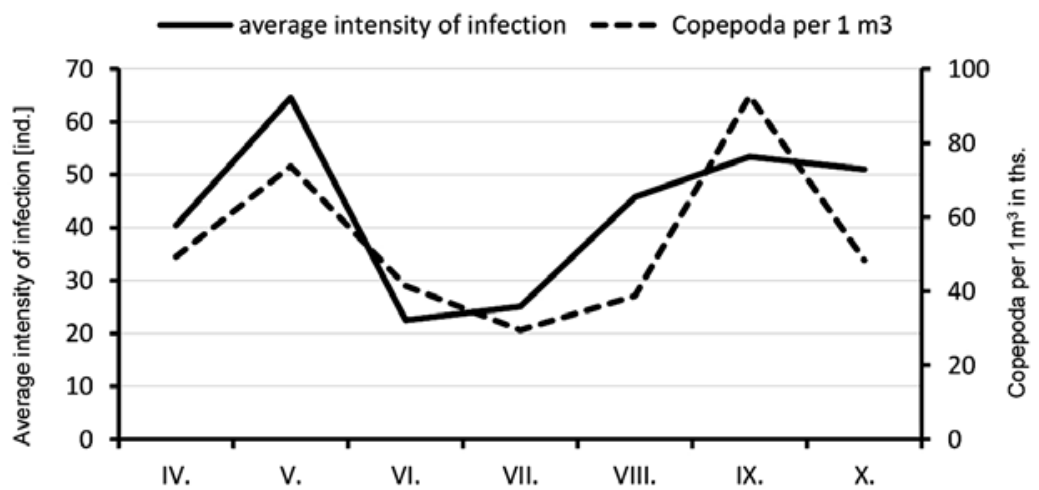

Fig. 7. Mean infection intensity of Ergasilus sieboldi (ind.) in relation to zooplankton development (Copepoda per $1 \mathrm{~m}^{3}$ in thousands) in the Koryčany reservoir from April (IV) to October (X) 2014.

same period (Fig. 8), with highly significant differences between the reservoirs during January to March, June to September and in December $(P<0.001)$, and during May and October to November $(P<0.05)$. The highest difference of temperature between reservoirs was in August. The mean temperature in August in the Hubenov reservoir was lower by $1.8{ }^{\circ} \mathrm{C}$ compared to the Koryčany reservoir. There was no significant difference in temperatures between the reservoirs in April $(P>0.05)$.

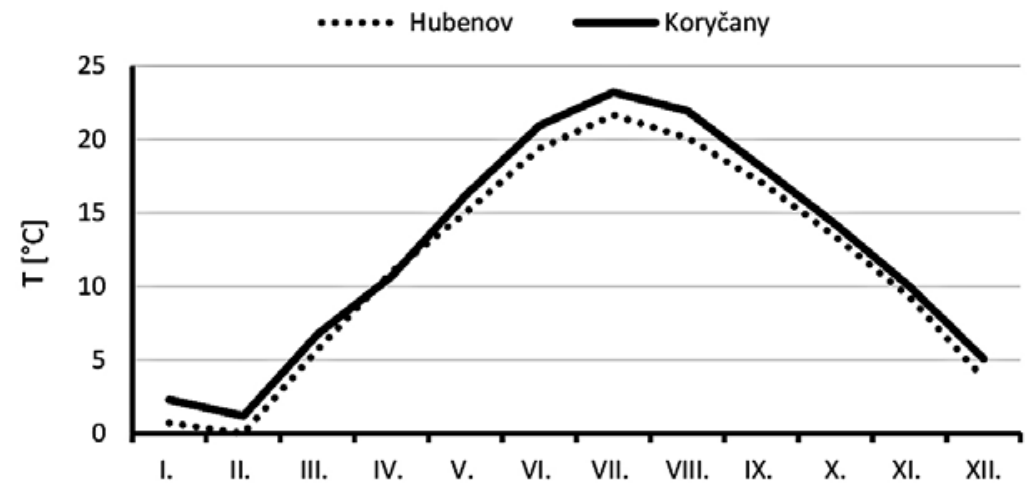

Fig. 8. Water temperatures in the Hubenov and Koryčany reservoirs during 2014.

\section{Discussion}

Values for parasite infection intensity, abundance and prevalence, along with Copepod zooplankton counts, changed throughout the monitored period in both reservoirs. The two peaks in E. sieboldi infection intensity and abundance recorded in June and September at Hubenov were most likely indicative of parasitisation by the first (June) and the second (September) generations of the parasite. At Koryčany, however, the first peak (the first generation attack) appeared earlier (May), most likely due to the higher water temperatures in this reservoir promoting faster egg development (see Piasecki et al. 
2004). Similarly, higher water temperatures may also have been responsible for extending the second generation attack, the increase in infection intensity and abundance extending through September into October. These values all decreased in the summer months at both reservoirs. These results correspond with those published by Lester and Hayward (2006) and Piasecki et al. (2004).

Prevalence reached relatively high values in both reservoirs throughout the monitoring period, though values were generally higher at Hubenov (80-100\%) compared to Koryčany (33-100\%). Similarly, values of the other epidemiological characteristics monitored also tended to be higher at Hubenov. These differences are almost certainly related to differences in zooplankton development, which in turn is impacted by the fish stock in the given reservoirs. Stocks of predatory fish are higher at Hubenov and this is likely to have suppressed the numbers of zooplanktonophagic fish to a greater degree than at Koryčany. Consequently, the abundance of E. sieboldi developmental stages is likely to have increased as a result of the drop in predation pressure on zooplankton (GrabdaKazubska 1988; Attayde and Hansson 2001; Beisner and Peres-Neto 2009). It is also possible that higher spring water levels at Koryčany may play a role, as the flooded reservoir margins provide suitable conditions for the spawning of phytophilic fish and also shelter for the fry. As a result, the subsequent increase in small-sized fish may suppress zooplankton to a larger degree at Koryčany. Differences in the seasonal dynamics of epidemiological characteristics may also be related to differences in water temperature, with generally higher temperatures at Koryčany speeding up parasite development.

The total abundance of copepods (ind. per $1 \mathrm{~m}^{3}$ ) at Hubenov was generally higher than at Koryčany, with copepod dynamics correlating well with those for epidemiological characteristics, e.g. infection intensity. This adds support to the hypothesis that zooplanktonophagic fish are suppressed by predatory fish, resulting in a higher abundance of E. sieboldi developmental stages. At Koryčany, seasonal ergasilosis dynamics were similar to those related to the development of copepods. It is possible that parasite development was so fast at Koryčany that peaks in the abundance of Copepoda and E. sieboldi infection intensity were recorded in the same month.

Predation pressure of fish on zooplankton is likely to have increased in the Koryčany reservoir as a result of increasing temperatures. This is manifested by decreased zooplankton abundance during the summer months. In contrast, fish predatory pressure decreased in autumn, resulting in an autumn peak in zooplankton abundance, as outlined under the plankton ecology group model (Sommer et al. 1986). It is also highly likely that the hatching of fish fry contributes greatly to the decrease in zooplankton during summer. In comparison to the Koryčany reservoir, pelagic zooplankton development differed at the Hubenov reservoir. For example, while parasite infection intensity and abundance showed two clear peaks, zooplankton abundance showed three peaks, with the highest abundance in May. This is probably due to the reduction in zooplanktonophagic fish brought about by the higher numbers of predatory fish at Hubenov. While summer zooplankton abundance levels were higher there compared to those at Koryčany, the autumn values were lower.

In conclusion, our results suggest that each reservoir represents a unique ecosystem for which it is difficult, if not impossible, to generalise seasonal development of ergasilosis. In our case, differences in parasite development appeared to be strongly related to the fish stock in each reservoir, which had a strong effect on zooplankton development.

More arthropod nauplius and copepod stages, which form part of the zooplankton assemblage, are likely to be found in reservoirs with low predatory pressure on zooplankton, i.e. where predatory fish suppress zooplanktonophagic fish. In this respect, while the stocking of predatory fish is desirable for maintaining water quality, it may also result in a steep increase in the development of ergasilosis. To date, no massive fish deaths from E. sieboldi infestation have been recorded in either reservoir; nevertheless, the occurrence 
of this parasite needs to be continuously monitored considering that unlike other fish parasites in reservoirs, it can occur at relatively high intensities. In this case, we suggest that monitoring adult females on fish gills may be inadequate and that more detailed zooplankton monitoring is required, with Ergasilus sp. being determined at the genus level.

\section{Acknowledgements}

Thanks are due to the employees of the Morava River Basin State Enterprise Fishery Department, for providing fish samples for parasitological examination, and employees of the Morava River Basin State Enterprise Hydrobiology Department, for obtaining and processing zooplankton samples.

\section{References}

Abdelhalim AI, Lewis JW, Boxshall GA 1991: The life-cycle of Ergasilus sieboldi Nordmann (Copepoda: Poecilostomatoida), parasitic on British freshwater fish. J Nat Hist 25: 559-582

Attayde JL, Hansson LA 2001: The relative importance of fish predation and excretion effects on planktonic communities. Limnol Oceanogr 46: 1001-1012

Beisner BE and Peres-Neto PR 2009: Seasonal trophic dynamics affect zooplankton community variability. Freshwater Biol 54: 2351-2363

Bernes C, Carpenter SR, Gårdmark A, Larsson P, Persson L, Skov Ch, Speed J DM, Donk E 2015: What is the influence of a reduction of planktivorous and benthivorous fish on water quality in temperate eutrophic lakes? A systematic review. Enviromental Evidence 4: 7

Bush AO, Lafferty KD, Lotz JM, Shostak AW 1997: Parasitology meets ecology on its own terms: Margolis et al revisited. International J Parasitol 83: 575-583

Dussart BH, Defay D 2001: Introduction to the Copepoda. Backhuys Publishers, Leiden, 344 p.

Dvurechenskaya SY, Yermolaeva NI 2014: Interrelations between chemical composition of water and characteristics of zooplankton in the Novosibirsk Reservoir. Contemp Probl Ecol 7: 465-473

Ergens R and Lom J 1970: Původci parasitárních nemocí ryb (Agents of parasitic diseases of fish, in Czech). Academia, Praha, 359 p.

Grabda-Kazubska B 1988: Effect of lake management on the parasite fauna of fishes. Wiadomości Parazytologiczne 34: $573-577$

Hoole D, Bucke D, Burgess P, Wellby I 2001: Diseases of carp and other cyprinid fishes. Fishing News Books, Malden, USA. 264 p.

Jurajda P, Adámek Z, Janáč M, Roche K, Mikl L, Rederer R, Zapletal T, Koza V, ŠpačekJ 2016: Use of multiple fish-removal methods during biomanipulation of a drinking water reservoir - Evaluation of the first four years. Fish Res 173: 101-108

Kestř́ánek J, Kříž H, Novotný S, Píše J, Vlček V 1984: Vodní toky a nádrže (Water flows and reservoirs, in Czech). Academia, Praha, 316 p.

Kubečka J, Frouzová J, Jůza T, Kratochvíl M, Prchalová M, Říha M 2010: Methodical guideline for the monitoring of fish communities of lakes and reservoirs. Biology centre AS CR, v.v.i., Institute of Hydrobiology, České Budějovice

Lester RJG, Hayward CJ 2006: Phylum Arthropoda. In: P. T. K. WOO, ed. Fish Diseases and Disorders. Volume 1: Protozoan and Metazoan Infections. CABI, Canada, $800 \mathrm{p}$.

Piasecki W, Goodwin AE, Eiras JC, Nowak BF 2004: Importance of Copepoda in Freshwater Aquaculture. Zool Stud 43: 193-205

Pichlová R, Brandl Z 2003: Predatory impact of Leptodora kindtii on zooplankton community in the Slapy Reservoir. Hydrobiologia 504: 177-184

Přikryl I 2006: Metodika odběru a zpracování vzorků zooplanktonu stojatých vod (Methodology of catching and processing samples of zooplankton of still waters, in Czech). VÚV TGM, Praha, $14 \mathrm{p}$.

Sommer U, Gliwicz ZM, Lampert W, Duncan A 1986: The PEG-model of seasonal succession of planktonic events in fresh waters. Arch Hydrobiol 106: 433-471

Sommer U, Adrian R, Domis LDS, Elser JJ, Gaedke U, Ibelings B, Jeppesen E, Lürlin, M, Molinero JC, Mooij WM, Donk E, Winder M 2012: Beyond the Plankton Ecology Group (PEG) Model: Mechanisms Driving Plankton Succession. Annu Rev Ecol, Evol, Syst 43: 429-448

Tatrai I, Mátyás K, Korponai J, Szabó G, Pomogyi P, Héri J 2005: Response of nutrients, plankton communities and macrophytes to fish manipulation in a small eutrophic wetland lake. International Rev Hydrobiol 9: $511-522$

Wolfinbarger WC1999: Influences of biotic and abiotic factors on seasonal succession of zooplankton in Hugo Reservoir, Oklahoma, U.S.A. Hydrobiologia 400: 13-31 